\title{
The Role of Climate Ethics in Biodiversity Conservation
}

\author{
By Mark Omorovie Ikeke ${ }^{1}$
}

\begin{abstract}
The environmental crisis manifests in various ways such as: desertification, deforestation, marine and atmospheric pollution, environmental racism, destruction of biodiversity and so forth. One of these, the destruction of biodiversity has continued unabated. Many factors have caused biodiversity loss. The most serious of these factors is climate change. This paper argues that to conserve biodiversity there is serious need to combat climate change. Combating climate change requires more than knowledge of scientific facts and public policy, there is need for climate ethics and ethically reconstructive human behaviours that act for climate justice. Through critical analytic and hermeneutic methods the concepts that ground the paper are interpreted and examined. The issues that the paper deals with are critically dissected and appraised. The paper finds that biodiversity loss is one of the most serious problems in the environmental crisis. The paper concludes that climate ethics can help to mitigate biodiversity loss.
\end{abstract}

Keywords: Climate Ethics, biodiversity, conservation, Biodiversity Conservation, environment, ecology, and environmental ethics

\section{Introduction}

Biodiversity is necessary for human and environmental sustainability. Biodiversity offers to humans many uses and benefits such as provision of food, pharmaceutical products for curing diseases, regulation of environmental problems, industrial and agricultural uses and meeting the needs of future generations (Francis, 2015, p. 23). But biodiversity should not simply be seen as resources to be exploited, for species have value in themselves also (Francis, 2015, p. 23). Without biodiversity human welfare and wellbeing is gravely threatened as essential eco-services to humans will be lost. Biodiversity is also useful for ecosystemic good. The great good that can come from biodiversity cannot be overestimated. Biodiversity loss is a public health concern as its loss could endanger vital resources needed by humans. The need for biodiversity made the United States Congress to pass the Endangered Species Act (US Congress, 1973). To preserve biodiversity, the United Nations also established the UN Biodiversity Convention. Professor Settele has stated that: "Ecosystems, species, wild populations, local varieties and breeds of domesticated plants and animals are shrinking, deteriorating or vanishing. The essential, interconnected web of life on Earth is getting smaller and increasingly frayed... This loss is a direct result of human activity and constitutes a direct threat to human well-being in all regions of the world" (Intergovernmental Science-Policy Platform on Biodiversity and Ecosystem Services, IPBES, 2019). 
The reality of biodiversity loss/extinction is indisputable. The fact is that since 1990 the average abundance of native species have fallen by $20 \%$, up to $40 \%$ of amphibian species are threatened, $33 \%$ of reef-forming corals are endangered, $10 \%$ of insects are threatened also; 680 species of vertebrate since the $16^{\text {th }}$ century have experienced extinction and more than $9 \%$ of domesticated breeds of mammals used in food and agriculture have gone into extinction since 2016 (IPBES, 2019). The IPBES report also clearly states that the major factors responsible for this biodiversity loss are: land and sea use changes, exploitation of organisms, climate change, pollution and invasive alien species. On climate change the report says that: "since 1980, greenhouse gas emissions have doubled, raising average global temperatures by at least 0.7 degrees Celsius - with climate change already impacting nature from the level of ecosystems to that of genetics - impacts expected to increase over the coming decades, in some cases surpassing the impact of land and sea use change and other drivers."

\section{Materials and Methods}

The study adopted qualitative and non-experimental methods of research in investigating the role of climate ethics in biodiversity conservation. It is based on data gathered from published books, journal articles, and online web sources. For each of the fundamental issues that the paper deals with such a climate ethics and biodiversity conservation, information and the ideas of different scholars from books and articles were consulted. Brief statistical data on the current state of biodiversity was sourced from the United Nations, International Union for Conservation of Nature websites. The key concepts that ground this paper are hermeneutically examined for better understanding of the issues. These key concepts are climate, ethics, climate ethics, biodiversity, conservation, biodiversity conservation and biodiversity loss. The effects of climate change on biodiversity conservation are presented. The role of climate ethics in combating biodiversity loss is then analysed.

\section{Results and Discussion}

\subsection{Conceptual Analysis}

The two predominant concepts that ground this paper are climate ethics and biodiversity conservation. The word, "climate" describes "the long-term weather pattern of a region" (Hook, 2008, p. 50). A broader definition of climate sees it as: "Accumulated general and averaged weather patterns (of) a considerable duration of a locality or region; the full description is based upon long-term statistics and includes extremes or deviations from the norm; climate is in contrast with weather, which is the state or the atmosphere at a particular time. Climate refers to yearly cycles of temperature, wind, rainfall, and so on, not daily variations" (Bellamy, 2007, p. 91). As for climate change it is change in climate arising directly or indirectly from human activities which alter global atmosphere composition (United Nations Framework on Convention on Climate Change, UNFCCC, 1992a). The definition of the UNFCCC limits climate changes to human activities. For another author, climate changes refer to "variations within the earth's atmosphere, processes in other parts of the earth such as oceans and ice caps, and the effects of human 
activity. Climate change is any long-term significant change in the 'average weather' that a given region experiences. Average weather may include average temperature, precipitation and wind patterns" (Rim-Rukeh, 2009, p. 473).

Having defined climate and climate change, what then is climate ethics? Ethics is concerned with codes, and regulations that guide human behaviour. Ethics is concerned with the moral standards for measuring human behaviour in terms of what is right and what is wrong. Ethics is "philosophy of human actions" (Njoku, 2018, p. 3). It is important to note that with the rise and coming into being of environmental ethics, ethics is no longer defined in terms of human behaviour to other humans. It also concerns human actions towards non-human beings and other entities. Climate change is due mainly to anthropogenic factors such as $\mathrm{CO} 2$, burning of fossil fuels, land-use patterns changes, deforestation and also methane gasses (Gardiner, 2010).

Climate ethics is concerned with climate change and its inherent challenges. It is concerned with human behaviours/actions in respect to the state of the climate that affect human lives and other realities in the universe. Human actions can aggravate the climate situation. Many environmental problems are attributable to human behaviours. A change in human behaviour is crucial to mitigating environmental problems. Restraining human behaviour to promote environmental values requires reducing unethical practices, imposing and enforcing strict sanctions, moral educational campaigns and rewarding good ethical behaviour. Combating biodiversity loss and extinction will require enacting and enforcing moral codes that make human beings mitigate climate change. Climate ethics is used in reference to human behaviours that precipitate climate change and what humans ought to do to mitigate and eradicate climate change. Whatever negative effects that climate change causes is a concern for climate ethics. In this work one of such negative effects is biodiversity loss. Therefore issues of biodiversity loss are concerns for climate ethicists. Human behaviours that cause climate change which in turn destroy biodiversity become an ethical question. Climate change and biodiversity loss are linked to ethical issues for it raises question on how human beings should live their lives. Should human beings continue to live and behave in ways that continue to emit more poisonous gasses into the air and water without moral restraint? One of the devastating effects of climate change is that the world becomes more humanized as there will be fewer plants and animals since they are dying out as a result of climate change (Jamieson, 2010).

Though biodiversity have different meanings, it is essentially "the range of different life forms that can be found in a given location or region" (Hook, 2008, p. 29). The biodiversity in locality is made up of plants, animals and other organisms in the area. Biodiversity could also be defined as: "...the numbers, variety, and variability of living organisms and ecosystems. The term includes the entire terrestrial, marine, and other aquatic organism. It also covers diversity within species, between species, as well as the variation among ecosystems. It is concerned also with their complex ecological interrelationships" (Rajagopalan, 2011, p. 67). Biodiversity is the "variability among living organisms from all sources including, inter alia, terrestrial, marine, and other aquatic ecosystems and the ecological complexes of which they are part" (United Nations, 1992b). On the origin and development of biodiversity, it should be realized that it comes from millions of years of dynamic historical evolutionary development producing new genetic variations depending 
on environment (Srivastava, 2010). Biodiversity is usually seen in three forms- species diversity, genetic diversity and ecosystem diversity (Srivastava, 2010). What then is biodiversity conservation? Biodiversity conservation deals with the activities of human beings in relationship to animals and plants; and developing ways to protect the diversity; and this conservation range from population protections of specific species and ecosystem preservation (Rajagopalan, 2011, p. 84). There are two main types of biodiversity conservation-on site in their natural habitat and off-site from their natural habitats (Rajagopalan, 2011, pp.84-85). Biodiversity conservation is "human efforts to collect, reverse, prevent or discontinue activities that are causing decline in biodiversity like pollution, deforestation, etc" (Srivastava, 2010).

Because this paper is concerned with biodiversity conservation, it is equally important to understand biodiversity loss or extinction. It is normally species that go into extinction. In the process of evolution, species can suffer extinction or be eliminated in a natural manner but it is the advent of human civilisation that has hastened the extinction of species and biodiversity loss (Srivatava, 2010). Biodiversity extinction is the death of a species (this is total elimination of all individual of a particular type), while biodiversity loss is the death of all the individuals of a species (this is extinction of a species). The Millennium Ecosystem Assessment presents the importance of biodiversity thus: "Biodiversity-the diversity of genes, populations, species, communities, and ecosystems-underlies all ecosystem processes. Ecological processes interacting with the atmosphere, geosphere, and hydrosphere determine the environment on which organisms, including people, depend. Direct benefits such as food crops, clean water, clean air, and aesthetic pleasures all depend on biodiversity, as does the persistence, stability, and productivity of natural systems" (2001).

\subsection{Some Factors Causing Biodiversity Destruction}

There are many factors that cause biodiversity destruction/extinction. One of the major causes of biodiversity destruction is global warming. When carbon dioxide is released into the atmosphere from burning of fossil fuel such as coal, gas, oil and other domestic and industrial activities it leads to climate change as global temperatures rise. Rise in temperature affects the wellbeing of plants and animals and other organisms in their habitats. This has led to the death of both flora and fauna as the heat from warming temperature become too much. As temperature rises ocean water rises and even gets warmer causing death of some sea animals and organism. Sea-level rise and extreme weather conditions precipitate environmental refugees, lead to climate change and biodiversity loss. Yet despite the value of biodiversity, it is seriously endangered by many factors such as climate change, air and marine pollution, overpopulation, urbanisation, industrialisation, war, violence, and so forth. The fact of the grave threat to biodiversity is acknowledged my many authors. Climate change that is the special concern of this paper is one of the gravest threats to biodiversity and its conservation. It is the gravest environmental threat to the planet and all planetary life as noted by world governments (Stranks, 2008).

Among many other factors that have caused biodiversity loss are loss of natural habitats of animals, plants and other organisms; poaching, human-wildlife conflicts, resources overexploitation, deforestation, etc (Srivastava 2010). Another cause of biodiversity loss is 
economic. The economic motive for profit and treasures motivated European colonialism. Economic development, industrialization and even globalization has led to the commodification and objectification of biodiversity as nature is simply seen as a resource and desacralized. Missionary activities of proselytizing religions that sees indigenous ecobeliefs as pagan, animistic have also accelerated the destruction of native cultures, trees, plants and sacred grooves.

\subsection{Some Effects of Climate Change}

Not every plant, animal or organism can thrive and survive when the temperature and environment is transformed. Anthropogenic activities often puts pressure on natural habitat of plants, animals and organism especially as human beings extend the built environment, build more factories, etc. It destroys the habitats of various life forms in the environment. Hook writes that: "When an ecosystem is subjected to some form of environmental pressure, its biodiversity usually suffers, and the extent to which this happens over time can be used as a measure of the likely long-term effects" (Hook, 2008, p. 29). With regard to plants and animals, "The life cycles of many wild plants and animals are closely linked to the passing of the seasons; climate changes can lead to interdependent pairs of species (e.g, wild flower and its pollinating insect) losing synchronization, if, for example, one has a cycle dependent on day length and the other on temperature or precipitation. In principle, at least, this could lead to extinctions or changes in the distribution and abundance of species" (Rim-Rukeh, 2009, p. 480). Climate change affects the migratory movement of some animals and birds. Some move from the southern hemisphere to the northern hemisphere if the temperature becomes hotter than the usual. In this process the service they offer is lost to the regions they are moving away from. Climate change then affects species multiplicity and distribution. Garvey writes that due to climate change ice caps in the Northern hemisphere are melting, the Arctic Sea is getting thinner, non-polar glaciers are also melting. He states that these realities have a negative effect on animals and plants that live in snow and ice such as the Polar bears that are now disappearing as the sea-ice they need to hunt is receding (2008, p. 10). Pope Francis corroborates this fact when he writes that:

...changes in climate, to which animals and plants cannot adapt, lead them to migrate; this in turn affects the livelihood of the poor, who are then forced to leave their homes, with great uncertainty for their future and that of their children. There has been a tragic rise in the number of migrants seeking to flee from the growing poverty caused by environmental degradation. They are not recognized by international conventions as refugees; they bear the loss of the lives they have left behind, without enjoying any legal protection whatsoever. Sadly, there is widespread indifference to such suffering, which is even now taking place throughout our world. Our lack of response to these tragedies involving our brothers and sisters points to the loss of that sense of responsibility for our fellow men and women upon which all civil society is founded (Francis, 2015, p. 20).

Rajagopalan list the followings as causes of biodiversity loss: habitat loss and degradation, destruction of tropical forests, destruction of wetlands and coral reefs, ploughing of grasslands, withdrawal of dam water and altered river systems, pollution of water sources (2011, p. 75). Every form of environmental degradation leads to some form of biodiversity loss. When streams and rivers are polluted it impacts some of the organism in them. When 
forests and grasslands are destroyed and cleared organisms are impacted. Ironically, these same human activities that lead to biodiversity loss also cause climate change. When human beings cut and burn forests to create human habitation or farms or build industries they expel carbon dioxide into the atmosphere. Human activities need to be restrained to the necessary minimum to curb climate change.

\subsection{Climate Ethics and Biodiversity Conservation}

The Intergovernmental Panel on Climate Change (IPCC) in its most authoritative and scientific report states that: "Natural, technical, and social sciences can provide essential information and evidence needed for decisions on what constitutes 'dangerous anthropogenic interference with the climate system.' At the same time, such decisions are value judgements" (IPCC, 2001) This statement is a clear indication that beyond science, economics, and other disciplinary contributions climate change is fundamentally an ethical issue as it relates to value questions. There is a place for climate ethics then in biodiversity conservation and climate change mitigation. The questions of climate change and biodiversity conservation are ones that affect other human lives on the planet, outside non-human lives. Note that:

If we do not think that our own actions are open to moral assessment or that various interests (our own, those of our kin and country, those of distant people, future people, animals, and nature) matter, then it is hard to see why climate change (or much else) poses a problem. But once we see this, then we appear to need some account of moral responsibility morally interests, and what to do about both. And this puts us squarely in the domain of ethics (Gardiner, 2010, p. 87).

Gardiner argues further that: "At a more practical level, ethical questions are fundamental to the main policy decisions that must be made, such as where to set a global ceiling for greenhouse-gas emissions and how to distribute the emissions allowed by such ceilings" (2010, p. 87).

Climate ethics which is concerned with curbing climate change is an imperative. . This paper argues that conserving biodiversity requires mitigating climate change. It should be noted that: "Climate change is now the biggest threat to natural World Heritage, according to a report published today by International Union for Conservation of Nature(IUCN). A third $(33 \%)$ of natural World Heritage sites are threatened by climate change, including the world's largest coral reef, the Great Barrier Reef, assessed as having a "critical" outlook for the first time." (International Union for Conservation of Nature, 2020)

Climate change in turn can be mitigated through climate ethics. Climate change has great impacts on human beings. As important as the issue of climate change, it is interesting to note that only few moral philosophers such as John Broome, Henry Shue, Dale Jamieson, Gardiner, Singer, etc have written about it (Gardiner, 2010). The concern of this paper is that beyond its negative impact on human beings, climate change has great negative impact on biodiversity. It should be borne in mind clearly that climate ethics is equally for biodiversity conservation. This rallying cry calls for respect and even veneration of all life. Though debatable it is gaining wide acceptance that preserving endangered animals and plants is an ethical issue for human beings should not act to destroy the richly endowed biological world. The fact is that other organisms have right to live also; and the human responsibility should not be to destroy but protect. Climate change is a serious moral issue 
and should be of concern to ethicists and all humanity (Gardiner, 2010). The question of global climate change is a moral one for it concerns how human beings ought to live, how they should relate to non-human life forms and the kind of societies human beings desire to create (Jamieson, 2010). Realize that human responsibility for climate change takes us into the arena of the philosophical (Irwin, 2010)

It does not show the humaneness of human beings to neglect biodiversity loss. When climate ethics helps to curb climate change then by implications it is helping to conserve biodiversity. The preceding shows that a major cause of biodiversity destruction/extinction is global warming/climate change. This is where the issue of climate ethics comes into play. Knowing the fact of climate change or biodiversity loss is not enough, human beings and industries should be morally convinced and act to end climate change. Garvey writes that: "The scientific facts are a necessary part of reflection on climate change, but they are nothing near the whole of it. Science can tell us what is going on, but not what we should do about it, What we should do depends largely on what we value and how we think about our values" (Garvey, p. 33). Science should be informed by human ethics and also ecological values. Climate ethics helps human beings and industries critically reflect on what is happening to plants and animals. Human beings are moral animals and conscious beings. They make decisions and act on choices. Those decisions and choices should be deliberate and impact the earth on which they live in a positive and ethical manner. If not for anything for the ecosystemic, cultural and other values that human beings derive from biodiversity, they should act in a moral manner to conserve biodiversity. There are rational moral grounds for conserving biodiversity as seen previously.

Global warming and climate change can be mitigated with enforceable climate ethics. Ethics as known regulates and guides human behaviour. Since most of the causes of global warming and climate change are anthropogenic, ethics is necessary. Much human behaviour is a product of human decisions and choices. When human behaviour is not regulated anything becomes the order of the day. Climate ethics should blossom into public policy and environmental laws to regulate human and industrial behaviours and activities that unnecessarily harm biodiversity. It is true that human beings can make use of resources from nature to sustain themselves. But this should be done in a manner that considers the wellbeing and interests of other biotic life forms. The right of human beings should not destroy the good of the earth community.

Environmental public policy is important in every country. This environmental public policy should be based on ethical value of biodiversity. It is a human responsibility to conserve biodiversity for the good of human beings and the biotic community. Human beings have a right to life and the factors that enhances that right. Biodiversity for instance is needed to produce a healthy natural environment where human beings can retreat and recreate. Ethical regulations to stop human beings from damaging biodiversity then are in place. Human activities like bush burning, excavating for coal, polluting oil and gas exploration methods, etc need to be stopped. Many will agree that human beings have indirect duties to plants and animals as their preservation help human beings in their food and survival needs (Holmes, 1989). Ethics shows personal change in lifestyle. Acting rightly in ethical self-restraint can make a difference. Behaviour modification is important to curb climate change and mitigate biodiversity loss. Holmes has argued for moving 
beyond seeing biodiversity simply from an instrumental perspective. Biodiversity should also be seen from an intrinsic and ecosystemic perspective (Holmes, 1994). The debate whether biodiversity should be preserved from an enlightened human interest perspective or for the sake of ecosystems is not the concern of this present paper. What is important for this paper is that biodiversity should be conserved.

Policy is not enough it should be morally driven. People need to be convinced morally of the need for biodiversity. When people are not convinced in their hearts and minds on the need for conserving biodiversity by ending climate change and other problems they are hesitant to act in the right manner. The climate ethics that is proposed here is not for its own sake. The climate change is mitigated for the sake of human beings and also for biodiversity wellbeing. Climate ethics will help mitigate the anthropogenic forces that cause and enhance climate change. This will thereby help in biodiversity conservation.

It is important to note that climate ethics is not monolithic. One's climate ethics is influenced by one's beliefs about humans and non-human nature. Different environmental views inform what one would consider to be an adequate climate ethics. Different environmental ethics include the followings: ecocentric ethics, biocentric ethics, anthropocentric ethics, eco-liberation ethics, ecofeminist ethics, deep ecology ethics, etc. Anthropocentric ethics will not see anything wrong in biodiversity loss unless it affects human beings. Loss for instance in distant islands not accessible to human does not certainly matter. For an ecocentrist loss of any part of nature even in islands that are not accessible to human beings is a great deal. For an anthropocentrist it is only climate change that affects human beings that should really matter. This paper argues for a total climate ethics goes beyond human anthropocentric interests. Combating climate change and by implication ameliorating biodiversity loss requires changes in human lifestyles, consumption patterns and production to mitigate global warming (Francis, 2015, p. 19). The model of development centered on fossil fuels, agricultural land use and deforestation all have to be transformed (Francis, 2015, p. 19). The reality is that much devastation caused by climate change on species and also humans places an onerous moral responsibility to curb it. If even not for the sake of biodiversity, it is a human responsibility to mitigate suffering caused to other human beings arising from climate change. The imperative of climate ethics that helps human beings to transforms their behaviours for the wellbeing of the planet is a quintessential.

Biodiversity conservators, policy planners and indeed all human institutions need to take serious the issue of climate change and ethics. Since climate change is one of the most destructive forces that endangers and destroys biodiversity they need to know what is climate change and ethics. Climate ethics will help in biodiversity conservation. Following the values and principles propelled by climate ethics helps to keep the earth and her natural resources and Fiona and fauna from the dangerous effects of global warming. While it is true that law/policy and ethics are not the same. They share in the purpose to order human welfare and wellbeing. Law/policy is rooted in what a people consider as valuable and so it borders on ethics. The Endangered Species Act is a case in point.

\section{Conclusion}

This paper has examined the role of climate ethics in conserving biodiversity. The 
paper made some conceptual analyses and clarification. The importance of biodiversity to the ecosystems and humanity were also examined. Among these benefits are that biodiversity helps in creating healthy ecosystems, provide food and pharmaceutical resources for humans, helps in environmental sustainability and so forth. The paper also looked at the negative effects of biodiversity loss and what can be done to curb biodiversity loss. A major thing that can be done to curb biodiversity loss is the implementation of climate ethics. Climate change is more often than not anthropogenic. And so human behaviour is important in curbing it. On a final note, the paper concludes by affirming that climate ethics can help in conserving biodiversity.

\section{References}

Bellamy, P. (2007). Academic's dictionary of environment. New Delhi: Academic (India) Publisher.

Francis, P. (2015). Laudato Si': Encyclical letter of the Holy Father Francis on care for our common home. Nairobi: Paulines Publications Africa.

Gardiner, S.M., (2010). Ethics and global climate change. In Stephen M Gardiner, Simon Caney, Dale Jamieson and Henry Shue (eds.), Climate Ethics: Essential readings, pp. 3-35. Oxford: Oxford University Press.

Garvey, J. (2008). The Ethics of Climate Change. London: Continuum.

Holmes, R. (1989). Philosophy gone wild: Environmental Ethics. Amherst, New York: Prometheus Books. . (1994). Conserving natural values. New York: Columbia University Press.

Hook, P. (2008). The little book of environmental principles. London: New Holland Publishers.

Intergovernmental Panel on Climate Change. (2001). Scientific assessment and value judgments. Accessed $20 \mathrm{March}$ 2021, from https://archive.ipcc.ch/publications_and_data/ar4/wg2/en/ch19s19-1-2-2.html

Intergovernmental Science-Policy Platform on Biodiversity and Ecosystem Services. (2019). UN Report: Nature's dangerous decline 'Unprecedented'; Species extinction rates 'accelerating. Accessed 20 March 2020, from https://www.un.org/sustainabledevelopment/blog/2019/05/nature-decline-unprecedentedreport/

International Union for the Conservation of Nature. (2020). Climate change now top threat to natural world beritage - IUCN report. Accessed 20 March 2020, from https://www.iucn.org/news/secretariat/202012 / climate-change-now-top-threat-natural-world-heritage-iucn-report

Irwin, R. (2010). Reflections on modern climate change and finitude. In Ruth Irwin (ed.), Climate change and philosophy, pp. 48-72. London: Continuum.

Jamieson, D. (2010). Ethics, public policy, and global warming. In Stephen M Gardiner, Simon Caney, Dale Jamieson and Henry Shue (eds.), Climate Ethics: Essential Readings, pp. 77-86. Oxford: Oxford University Press.

Millennium Ecosystem Assessment. (2001).Accessed 20 March 2021, from https://www.millenniumassessment.org/en/index.html

Rajagopalan, R. (2011). Environmental Studies: From Crisis to cure. Oxford: Oxford University Press.

Njoku, F.O. (2018). Studies in Ethics. Lagos: Claretian Publishers.

Rim-Rukeh, A. (2009). Environmental Science: An introduction. Ibadan: Kraft Books.

Srivastava, S. (2010). Environmental Science and Etbics. New Delhi: S K Kataria \& Sons.

Stranks, J. (2008). The A-Z of the environment: A complete guide to all the issues-scientific, legal, economic and social- and their impact on business and government. London: Thorogood Publishing.

United Nations. (1992a). United Nations Framework on Climate Change. Accessed 20 March 2021, from https://unfccc.int/files/essential_background/background_publications_htmlpdf/application/pd f/conveng.pdf

(1992b). Convention on Biological Diversity. Accessed 20 March 2021, from https://www.cbd.int/doc/legal/cbd-en.pdf

US Congress. (1973). The Endangered Species Act. Accessed 20 March 2021, from https://www.epa.gov/lawsregulations/summary-endangered-species-act 